\title{
Okul Öncesi Dönemde Kronolojik Düşünme: Bir Durum
}

\author{
Çalışması ${ }^{*}$
}

\begin{abstract}
Kibar AKTIN $\quad$ Dursun DİLEK ${ }^{* * *}$
Öz

$\mathrm{Bu}$ çalışmada erken çocukluk dönemi kronolojik düşünme becerilerini ortaya koymak ve çocukların bu becerileri nasıl işe koştuklarını sorgulamak amaçlanmıştır. Araştırmanın çalışma grubunu 2012-2013 eğitim-öğretim yılında anaokuluna devam eden 4,5-6 yaş arası 12 çocuk oluşturmuştur. Araştırma nitel bir çalışma olup durum çalışması deseni kullanılmıştır. Araştırmanın verilerini görsel zaman çizelgesi dokümanları ve zaman çizelgesi üzerine çocuklarla yapılan görüşme kayıtları oluşturmaktadır. Veriler betimsel ve içerik analizi tekniğine uygun olarak çözümlenmiştir. Araştırmadan elde edilen sonuçlar 4,5 ile 6 yaş arası çocukların kronolojik sıralamada ortalamanın üzerinde bir başarı gösterdiklerini ortaya koymuştur. Çocukların kronolojik düşünmede, genel olarak en uzak zamana ait materyalleri belirlemede neden sonuç ilişkisi içerisinde malzemenin özelliğine ve rengine dayalı olarak ve yer yer sezgisel ve/veya çağrışımsal düşünerek çıkarımda bulundukları; daha yakın zamana ait materyalleri belirlemede ise geçmiş zamana ait gezip gördükleri mekânı ve yaşlı insanları referans aldıkları; en yakın zamana ait materyalleri kronolojik sıralarken de neden sonuç ilişkisi içerisinde malzemenin özelliği ile ya da kendi günlük yaşam alanı içerisinde deneyimledikleriyle ilişkilendirdikleri görülmüştür.
\end{abstract}

Anahtar Kelimeler: Erken çocukluk eğitimi; tarih eğitimi; kronolojik düşünme; kronolojik siralama.

\section{Chronological Thinking at Preschool Period: A Case Study}

\begin{abstract}
This study aims to explore early childhood chronological thinking skills and to inquire how children use these skills. Sample of the study consisted of 12 children aged 4,5-6 who attended preschool in the academic year of 2012-2013. This is a qualitative research that use case study design. Research data consisted of visual timeline documents that children created and interview recordings of children about the timeline. Data were analyzed using descriptive and content analyses. It is found that children aged between 4.5 and 6 showed success in the chronological sequences above the average. In general,it was observed that when children used chronological thinking, they made inferences partly through thinking intuitively and/or associatively based on properties and colors of the materials to determine the materials that belong to the most distant time in relation to "cause and effect" ; when determining materials that belong to the more recent past, they used historical places that they visited and older people as references; when arranging
\end{abstract}

\footnotetext{
${ }^{*}$ Bu araştırma 3-6 Şubat 2016 tarihinde IX. Avrupa Sosyal Bilimler ve Davranış Bilimleri Konferansında ( IX. European Conference on Social Behavioral Sciences Paris, France) sunulan ve bildiri kitapçı̆̆ında özet olarak yer alan aynı adlı bildirinin genişletilmiş ve geliştirilmiş halidir.

** Yrd. Doç. Dr., Sinop Üniversitesi, Eğitim Fakültesi, Temel Eğitim Bölümü, kibaraktin@yahoo.com

*** Prof. Dr., Sinop Üniversitesi, Eğitim Fakültesi, Sosyal Bilgiler ve Türkçe Eğitimi Bölümü, dursundilek@sinop.edu.tr
} 
the materials that belong to the most recent time in a chronological order, they associated this order with the properties of the materials or their own daily experiences in relation to "cause and effect".

Keywords: Early childhood education; history education; chronological thinking; chronological sequences.

\section{GİRIŞ}

Zaman kavramı, erken çocukluk döneminde kazanımı zor olan bir beceri olarak bilinir. Yaptıkları araştırmalarla Piaget ve onu destekleyenler özellikle kronolojik sıralamayı içeren bir zaman kavramını öğrenmenin küçük çocuklar için sıklıkla zor olduğunu ileri sürerler. $\mathrm{Bu}$ durumu zaman kavraminin soyut olması ile ilişkilendirirler (Zakay, 1989'dan akt. Zembat, Ünsal, Yazıcı, Küçükoğlu, Yıldız ve Tunçeli, 2014: 210; Murray 1969'dan akt. Levin, Israeli ve Darom, 1978: 756). Aslında çocuklar zaman kavramıla, günlük yaşam deneyimleri içerisinde, aile büyüklerinin anlatılarında çok erken yaşlarda sıkça karşılaşmalarına rağmen, yapılan gözlemlerde küçük çocukların yaşam içerisinde bulundukları ana yönelik kavramları rahatça kullandıkları, geçmiş ve geleceğe dair kavramları ise kullanmakta zorlandıkları görülür (Zembat vd., 2014: 210). Geçmiş ve gelecek zaman kavramının anlaşılmasındaki güçlük küçük çocukların alışıldık sıralamanın dışında ileriye doğru zihinsel eylemde bulunmaları ile gelecek zamanı, geçmiş zaman kavramından önce öğrenmeleri ile ilişkilidir (Friedman, 2000, Akt. Kol, 2012: 41). Friedman (1991: 154) araştırmasında 4 yaşındaki çocukların genel olarak birbirine yakın basit (konvansiyonel) zamanlı (dün, bugün, yarın) olayları ayırt edebildiklerini bir günden daha uzun ölçekli fiziksel zamanı (geçmiş, bugün ve gelecek) ayırt etmede zorlandıklarını ortaya koymuştur. Genel olarak, 4 yaşındaki çocukların çoğunlukla büyük ölçekli geçici yapıya sahip olma düzeylerinin düşük olduğunu, mevsimler, aylar ve haftanın günlerini ve okullarının gelecekteki birkaç yıllık durumu ile ilgili şeyleri öğrenebildiklerini ifade etmektedir.

Piaget ise zaman karmaşasını çocuklarda işlem öncesi dönemde (2-6 yaş) süreç ve sıralamanın geçici olmaktan daha ziyade uzamsal (yer) olarak algılanmasıyla ilişkilendirir. Ona göre küçük çocuklarda zaman kavramı yer kavramından kaynaklanır. Zamanın öncesi ve sonrası bir yerin öncesi ve sonrası ile karışır. Bu nedenle küçük çocuklar uzak bir mesafeyi uzun bir süreç olarak ifade ederler (Levin vd., 1978: 755; Friedman, 1991: 139). Benzer bir şekilde Levin $(1977,1979)$, çocukların hız ve mesafe ile şekillenen zamanla ilgili kafa karışıklığının zamanın nicel boyutları arasındaki kavramsal farklılıkları açıklayamamalarına neden olduğunu belirtmektedir (Levin ve Gilat, 1983: 78, 83). Çocuğun mesafe ve hizı mantıklı olarak kavrayamadığı için ortaya çıkan bu durum "uzun mesafe" modeli olarak adlandirılır. Yapılan farklı çalışmalarda Piaget bu modelin varlığını ortaya koyar (Piaget 1969, akt. Berndt and Wood, 1974: 825). Piaget çocuğun uzaysal zaman kavramindan doğrusal kronolojik bir sıralama anlayışına soyut işlemler döneminde ulaşabileceğini ifade eder (Smith ve Thomlinson, 1977, Akt: Dilek, 2007). Buna karşın Berndt ve Wood (1974: 827) Piaget'nin (1969) ileri sürdüğü hipotezin tersine işlem öncesi dönemde çocuğun süreci belirlediği ilkel bir kapasiteye sahip olduğunu tespit eder. Strube, Weber (1988) gibi Friedman da (1991) yaptıkları araştırmada 5 yaş çocuklarının zaman içinde uzamsal bağlamı dikkate almaksızın geçmiş olayların mesafesine karar verebildiklerini görür (Friedman, 1991: 154). Levin ve diğerleri de (1978: 755) yaptıkları araştırmalarda süreç ve sıralamanın benzer aşamalarda zor anlaşıldığını ya da paralel geliştiğini görür.

Seefeldt, Castle ve Falconer (2015: 209) kronolojik düşünmeyi uygulamalı zaman olarak nitelemektedir. Onlar kronolojik düşünmenin "ardışıklık ve süreklilik ilişkisi" içerdiğine dair bir anlayışa vurgu yaparlar. Süreç ve sıralama kavramları kronoloik düşünme becerisinin iki önemli öğesidir. Burada bahsedilen kronoloji, olayların doğrusal tarihsel bir sıralamasıdır ve tarihsel düşünmenin merkezinde oturur. Kronolojik düşünme kronolijinin aksine daha kompleks bir olgudur. Sebep sonuç ilişkisini ve zaman içerisindeki değişimi anlamayı içerir. Kronolojik düşünmenin ortaya çıkabilmesi için öğretmen tarafindan çocuklara teknoloji, değerler, kurumlar, gelenekler ve inançlardaki değişimin belirtilmesi ve yorumlatılması önerilmektedir. Bu aşamada öğretmenin tarihsel 
süreçteki ve tarihsel sıralamadaki yapıyı vurgulamasıyla birlikte, tarihsel süreçte değişim ve süreklilik arz eden tarihsel yapıları da göstermesi önemlidir. Böylece öğretmen, çocukların kronolojik düşünmesinde belirli bir zaman periyodunda ilişkileri sebep sonuç ilişkisi içerisinde anlamalarına yardımcı olacaktır. (Drake ve Nelson, 2005: 83). Seefeldt de (2005) karmaşık bir bileşim olan zamanı içeren kronolojik anlamanın değişim ve sebep gibi anahtar kavramlarla birlikte bireylerde zaman duygusunun gelişimine dayandığına dikkat çeker (Akt. Çoşkun-Keskin, 2016).

Piaget'nin (1977) ileri sürdüğü bilişsel gelişim teorisi eğitim alanında genel kabul görmüş bir yaklaşımdır. $\mathrm{Bu}$ yaklaşımın tarih öğretimine uyarlanması ise soyut işlemler evresinde bulunmayan çocukların soyut bir alan olan tarihi anlayamayacaklarını (Aktın ve Dilek, 2014: 35; Dilek, 2007: 67) ve kronolojik düşünme becerilerinin gelişemeyeceği anlayışını beraberinde getirir. Stow ve Haydn (2000: 95) çocuklarda öğrenmelerin "farklı yaşlarda farklı hızlarda" olduğu gerçeği üzerinden tarihsel bir zaman algısının oluşumunu yaş ile ilişkilendirmeyi doğru bulmamaktadır. Benzer bir yaklaşımla Vygotsky (1986) ve Donaldson (1978) çocukların öğrenme kapasitelerinin artmasının yaşla sınırlama yerine sosyal çevrenin desteğiyle arttığına yönelik bir yaklaşım ortaya koymuşlardır (Çulha-Özbaş ve Aslan, 2008: 105). Zembat ve diğerleri de (2014: 210) küçük bir çocuğun geride kalan bir zamanı tanımlarken hafızasını, dikkatini, algısını ve dil gelişimini birlikte işe koştuğunu belirtir. Bu şekilde çocuğun geçmişte olan şeyleri hatırlamasının ve özel ayrıntılara dikkat etmesinin sağlanabileceğini ve geçmiş algısının geliştirilebilir olacağını savunurlar.

Thornton ve Vukelich (1988) belirli tarihsel zaman ve tarih kavramlarının 6 yaşına kadar olan çocukların sınırları dâhilinde olduğunu ve çocuklara her kavramı mantıklı ve sistematik olarak sıralamanın öğretilebileceğini ileri sürmektedirler. Onlar geçmişle ilgili söylenen şeylerde çocukların zamanla ilgili dil ve kavramları anlamaları için tarihsel kavramanın tarihsel konularla nasıl sağlanacağının belirlenmesinin ve üzerinde düşünülmesinin gerekliliğini vurgulamaktadırlar (Akt. Alleman ve Brophy, 2003: 107). Birçok araştırmacı da bilişsel gelişim teorilerine bağlı kalmaksızın çocuklara sunulan zengin öğrenme çevresi ve yaşantılarla zaman algısının geliştirilebilen bir beceri olduğunu ortaya koymaktadır (Alleman ve Brophy, 2003: 107; Egan, 1982; Vukelich ve Thorndon, 1990; Dilek, 2007; Zembat vd., 2014; Hacısalihoğlu-Karadeniz, 2013). Nitekim Zembat, Özdemir-Beceren, Şengül ve Ünsal (2013) yaptıkları araştırmada geçmişlik içeren aktivitelerde çocukların kendi yaşamlarındaki değişimle ilgilendikleri, değişim, gelişim ve reform kavramlarını anladıklarını ve çocukların olayların kronolojik sıralamasını daha iyi kavradıklarını tespit etmişlerdir. Seefeldt'da (2005) erken çocukluk döneminde çocukların geçmişi bugünden ayırt ettiklerini ve "sıralı örneklerle günlük olayları tanımlamaya" başladıklarına dikkat çeker (Akt. Çoskun-Keskin, 2016).

Yapılan araştırmalarda okul öncesi eğitimde zamanla ilgili algının geliştirilebileceği ve kronolojik düşünme becerisinin geliştirilmesine dair ilk adımların atılacağı ileri sürülmektedir. Türkiye'de Okul Öncesi Eğitim Programı incelendiğinde zamanla ilgili kazanımlara "Bilişsel Gelişimle İlgili Kazanımlar" içerisinde rastlanmaktadır. Bu başlık altında 18. Kazanım "Zamanla ilgili kavramları açıklar", göstergeleri "Olayları oluş zamanına göre sıralar. Zamanla ilgili kavramları anlamına uygun şekilde açıklar. Zaman bildiren araçların işlevini açılar" ifadelerini içermektedir. Zamanla ilgili kazanıma dair açıklamalar "Çocukların kendi yaşantılarına ilişkin deneyimleri ile 'dün oynadığımız oyun', 'bugün gideceğimiz gezi', 'yarın okula gelecek misafir' gibi zaman bildiren kavramlar etkinliklerle bütünleştirilerek ele alınmalıdır. Ayrica sinıftaki saat ve takvimlerin kullanılmasına çocuklar da dâhil edilmeli ve işlevlerine dikkat çekilmelidir." ifadelerini içermektedir (MEB, 2013: 23). Açılklamalar zaman kavramı öğretiminde fiziksel bir zamandan ziyade daha çok basit zamanın kazanımına dair etkinlikleri içermektedir. Programdaki bu eksiklik ve Türkiye'de konuyla ilgili yapılan çalışmaların sınırlılığı da göz önüne alındığında okul öncesi eğitimde zaman ve kronolojik düşünme becerileri üzerinde yapılacak kuramsal ve uygulamaya yönelik çalı̧̧malara ihtiyaç olduğu söylenebilir. Bu ihtiyaçtan hareketle araştırmanın amacı 21. yüzyılda erken 
çocuklukta çocukların kronolojik düşünme becerisini etkileyen faktörleri belirlemek ve kronolojik düşünme becerilerinin nasıl geliştirilebileceğinin cevabını bulmaya çalışmaktır.

Araştırmada çocukların kronolojik düşünme becerisini etkileyen faktörler eldeki dokümanlardan ve kendi görüşlerinden hareketle aşağıdaki alt problemler kapsamında incelenmiştir:

- Çocuklar ikili ve üçlü görsel zaman çizelgesini kronolojik olarak sıralayabilmekte midir?

- Çocuklar kronolojik düşünme sürecinde uzak geçmişe ait materyali nasıl belirlemektedir?

- Çocuklar kronolojik düşünme sürecinde yakın geçmişe ait materyali nasıl belirlemektedir?

- Çocuklar kronolojik düşünme sürecinde şu ana ait materyali nasil belirlemektedir?

\section{YÖNTEM}

$\mathrm{Bu}$ araştırmada, nitel araştırma desenlerinden durum çalışması kullanılmıştır. Durum çalışması deseni insanlar, gruplar, kurumlar, farklı topluluklar ve hatta ülkelerle ilgili belirli olguları açiklamak ve tanımlamak için durumu kendi koşulları içerisinde inceleyen sosyal bir çalışmadır (Yin, 1984, akt. Sönmez ve Alacapınar, 2013; Seggie ve Bayburt, 2015: 122). Araştırmada, durum çalışması desenlerinden birisi olan "iç içe geçmiş tek durum" deseni kullanılmıştır. Desende genellikle bir durum çok sayıda tabaka veya birimden oluşabilmektedir (Yıldırım ve Şimşek, 2008: 291). Araştırmada bu durum içinde yer alan tabakaları okul öncesi sinıfindaki 52-60 aylık, 62-72 aylık çocuklar oluşturmaktadır. Belirlenen tabaka birimlerinin derinlemesine irdelenmesinin araştırma durumunu ayrıntılı bir şekilde açıklayacağı düşünülmektedir. $\mathrm{Bu}$ amaçla tabakalardan ayrı ayrı elde edilen verilerden yola çıkılarak, araştırma durumunun bütününe ilişkin sonuçlar elde edilmeye çalışılmıştır.

\section{1 Çalışma Grubu}

Araştırmanın çalışma grubu 2012-2013 eğitimöğretim yılında bir anaokuluna devam eden 28 çocuktan oluşmuştur. Araştırmanın hedef öğrencileri çalışma grubundan amaçlı örnekleme yöntemlerinden ölçüt örnekleme tekniği kullanılarak (52-60 aylık, 62-72 aylık çocuklar seçilerek) belirlenmiştir. Ölçüt örneklemede “[...] temel anlayış önceden belirlenmiş bir dizi ölçütü karşılayan bütün durumların çalışılmasıdır. Burada sözü edilen ölçüt veya ölçütler araştırmacı tarafından oluşturulabilir ya da daha önceden hazırlanmış bir ölçüt listesi"dir (Yıldırım ve Şimşek, 2008: 112). Bu doğrultuda araştırmanın çalışma hedef grubu 52-60 aylık küçük yaş grubu $(\mathrm{n}=5), 62-72$ aylık büyük yaş grubu (n=7) 12 çocuktan oluşmuştur.

Tablo 1. Çalışma Grubu İle İlgili Bilgiler

\begin{tabular}{ccc}
\hline Öğretmen Kodu & Cinsiyet & Yaş1 (Aylık) \\
\hline Ö1 & E & 52 \\
Ö2 & K & 57 \\
Ö3 & K & 57 \\
Ö4 & K & 58 \\
Ö5 & K & 60 \\
Ö6 & E & 62 \\
Ö7 & E & 67 \\
Ö8 & E & 67 \\
Ö9 & K & 68 \\
Ö10 & K & 71 \\
Ö11 & E & 72 \\
Ö12 & K & 72 \\
\hline
\end{tabular}

Analiz sürecinde çalışma grubundaki çocuklar 2.2 Araştırma Süreci ve Veri Toplama Araçları

Ö1, Ö2, Ö3, Ö4, Ö5, Ö6, Ö7, Ö8, Ö9, Ö10 şeklinde kodlanmıştır. Tablo 1'de görüldüğü gibi çalışma örneklemini büyük yaş grubunda 4,5-6 yaş arası 5 erkek ve 7 kız çocuğu oluşturmaktadır.

Sınıf içi uygulama süreci üç gün sürmüştür. $\mathrm{Bu}$ süreçte çocukların geçmiş yaşam koşullarında zamanla değişimi ve sürekliliği fark etmeleri 
sağlanarak kronolojik düşünme becerilerini geliştirmek amaçlanmıştır. Amaç çerçevesinde çalışmanın ilk günü çocuklara fotoğraflarla geçmişte yaşam temalı bir sunum yapılmıştır. Sunumda ulaşım araçları, ahşap evler, çadır ve taş evler, eski bir konak ve konakta kullanılan ev eşyaları gösterilmiştir. Sunumda fotoğraflar üzerinden konaktaki yaşam öyküleştirilerek anlatılmıştır. İkinci gün sanat etkinliğinde çocuklardan el işi kâğıtlarına çizilmiş cam, kapı ve pencereyi kesip kendilerine verilen ilgili maket evin (eski ya da yeni ev) üzerine yapıştırmaları istenilmiştir. Aynı etkinliğin devamında artık kumaş parçalarından çocukların imgeleme becerilerini de işe koşarak yeni ya da eski eve ait cam, kapı ve pencere yapmaları ve hazırladıkları bu materyalleri ilgili (eski ya da yeni ev) maket evin üzerine yapıştırmaları istenilmiştir.

Üçüncü gün çocukların kronolojik sıralama becerilerini değerlendirmek amaçlı görsel zaman çizelgesi oluşturma etkinliği yapılmış ve beraberinde zaman çizelgesi üzerine kendileriyle yapılandırılmış görüşme yapılmıştır. Yıldırım ve Şimşek'e (2008: 267) göre görüşme ve doküman analizi gibi "farklı yöntemlerle elde edilen verilerin birbirini teyit amaciyla kullanması, ulaşılan sonuçların geçerliğini ve güvenirliğini arttır[maktadır]". Görsel zaman çizelgesinde yer alan fotoğrafların oluşturulmasında ve görüşme sorularının hazırlanmasında tarih eğitimi alanında uzman iki öğretim üyesi ile işbirliği yapılmıştır. Sınıfta gerçekleştirilen geçmişte yaşam temalı etkinlikler doğrultusunda uzmanların da önerisi ile görsel zaman çizelgesi dünden bugüne süreklilik gösteren fakat değişime uğrayan yemek kaşıklarından tahta ve metal kaşık; ütülerden taş ütü, mangal ütü, yeni ütü; aydınlatma araçlarından mum, gaz lambası, ampul ve tarım araçlarından saban ve traktörden oluşturulmuştur. Uzmanların görüşleri doğrultusunda çizelgedeki fotoğraflar çocukların kronolojik sıralamada renge dayalı bir ipucu elde etmesini engellemek amaçlı siyah beyaz fotokopi olarak çekilmiştir (Bkz. Fotoğraf 1). Ayrıca hazırlanan bu formlar etkinlikte araştırmacılara yardımcı olan iki okul öncesi öğretmeninin ve çocuk gelişimi alanında uzman bir öğretim üyesinin görüşüne sunulmuştur. Alınan geri bildirimler doğrultusunda yeniden düzenlenen görsel zaman çizelgeleri ile çocuklarla pilot etkinlikler ve görüşmeler gerçekleştirilmiştir. Pilot çalışmadan elde edilen sonuçlar doğrultusunda düzenlemeler yapılarak görsel zaman çizelgelerine ve görüşme sorularına son şekli verilmiştir.

Görsel zaman çizelgesi oluşturma etkinliğinde çocuklara önce kaşıklar (ikili kronolojik sıralama), devamında ütüler (üçlü kronolojik sıralama), ardından aydınlatma araçları (üçlü kronolojik sıralama) ve son olarak tarım araçlarını içeren (ikili kronolojik sıralama) fotoğraflar verilmiştir. Çocukların her birine aşama aşama yönerge verilerek ikili ve üçlü fotoğraflardan hangisinin en eski ve sonrasında hangisinin daha yeni olduğunu kronolojik olarak sıralamaları ve bu esnada siralamayı nasıl yaptıklarını nedeni ya da nedenlerini açıklamalarına yönelik sorulara cevap vermeleri istemiştir. Çocuklara yöneltilen görüşme soruları sebep sonuç ilişkisi içerisinde çocukların zaman içerisindeki değişimi nasıl anladıklarını içerir. Çocukların kronolojik düşünme becerilerini ortaya çıkarmayı amaçlar. 


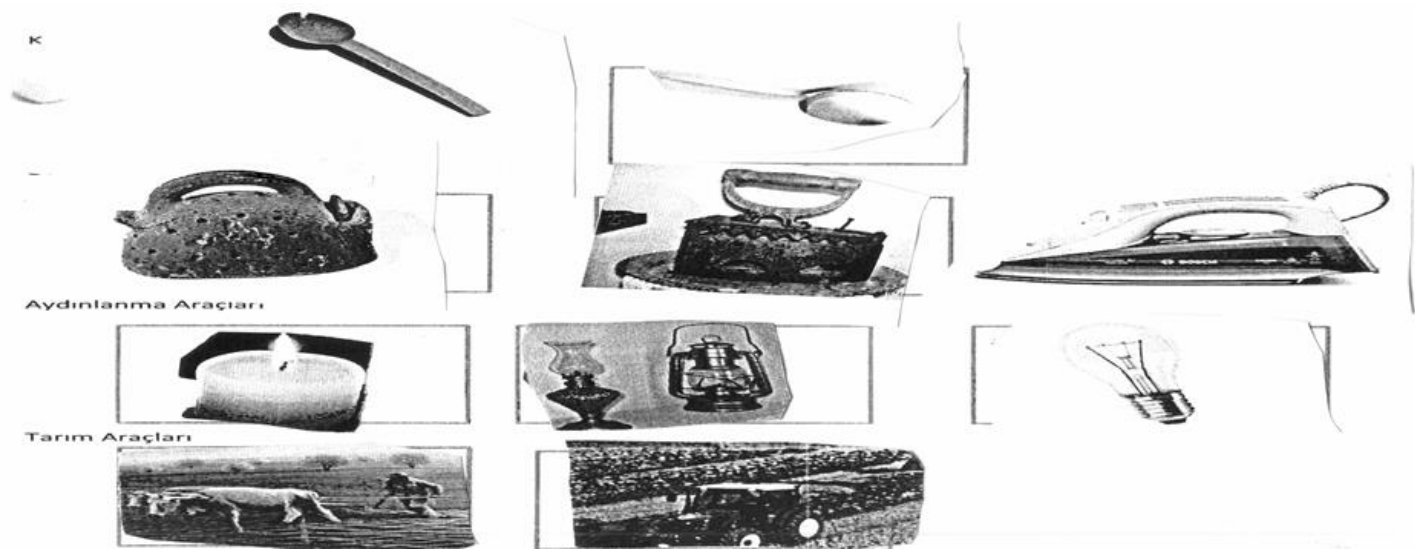

Resim 1. Kaşıklar, Ütüler, Aydınlatma ve Tarım Araçları Görsel Zaman Çizelgesi

Yapılandırılmış görüşme soruları görsel zaman çizelgelerini sıralayan çocukların erken çocukluk döneminde çocukların kronolojik düşünme becerilerini ortaya koymak ve çocukların bu becerileri nasıl işe koştuklarını tespit etmek amaçlı kaşıklar, ütüler, aydınlatma ve tarım araçları başlığı altında kategorize edilmiştir. Araştırmanin alt problemleri görüşme sorularının temel kategorilerini oluşturmaktadır. Görüşme soruları ve bu soruların dâhil olduğu temel kategoriler (alt problemler) aşağıdaki tabloda sunulmuştur.

Tablo 2. Görüşme soruları ve temel kategoriler

\begin{tabular}{l}
\hline Temel Kategoriler \\
\hline Kaşıkların kronolojik sıralamasın \\
belirleyen faktörler. \\
Ütülerin kronolojik sıralamasını \\
belirleyen faktörler.
\end{tabular}

Aydınlatma araçlarının kronolojik sıralamasını belirleyen faktörler.

Tarım araçlarının kronolojik sıralamasını belirleyen faktörler.
Sorular
Çocukların eski kaşı̆̆ı belirlemesinde etkili olan faktörler nelerdir?
Çocukların yeni kaşığı belirlemesinde etkili olan faktörler nelerdir?
Çocukların uzak geçmişe (en eski) ait ütüyü belirlemesinde etkili olan faktörler nelerdir?
Çocukların yakın zamana ait ütüyü belirlemesinde etkili olan faktörler nelerdir?
Çocukların yeni ütüyü belirlemesinde etkili olan faktörler nelerdir?
Çocukların uzak geçmişe ait aydınlatma aracını belirlemesinde etkili olan faktörler nelerdir?
Çocukların yakın geçmişe ait aydınlatma aracını belirlemesinde etkili olan faktörler nelerdir?
Çocukların yeni aydınlatma aracını belirlemesinde etkili olan faktörler nelerdir?
Çocukların geçmişe ait tarım aracını belirlemesinde etkili olan faktörler nelerdir?
Çocukların şimdiye ait tarım aracını belirlemesinde etkili olan faktörler nelerdir?

\subsection{Verilerin Analizi}

Veri toplama sürecinde her bir çocuk ile ortalama 10-15 dakika süren görüşmeler gerçekleştirilmiştir. Toplamda 150 dakikayı bulan görüşmeler ile birlikte gerçekleştirilen kronolojik sıralama etkinliği kamera ile kayıt altına alındıktan sonra görüşmelerin yazılı dökümleri çıkarılmıştır. Devamında kaşıklar, ütüler, aydınlatma araçları ve ütülerin kronolojik sıralamasını içeren dokümanların doğruluğu ve yanlışlığı tespit edilerek veri analizi frekans tablosu oluşturulmuştur. Görüşme verileri yazıya dökülerek betimsel ve içerik analizi yoluyla analiz edilmiştir. Betimsel analiz 
yaklaşım verilerin araştırma sorularının ortaya koyduğu temalara göre organize edilmesine ve kullanılan sorular veya boyutlar dikkate alınarak sunulmasına imkân vermektedir (Yıldırım ve Şimşek, 2008). Betimsel analiz için araştırmada daha önceden belirlenen temalar özetlenip yorumlanmıştır. $\mathrm{Bu}$ amaçla temalar geçmiş zamana ait sınıf içi anlatılardan hareketle belirlenen kavramsal çerçeveden yararlanılarak belirlenmiştir. Kodlama, daha önceden var olan genel kavramsal yapı temel alınarak gerçekleştirilmiş ve belirli kategoriler altında toplanmıştır. İçerik analizi toplanan verilerin derinlemesine analiziyle, önceden belli olmayan tema ve boyutların ortaya çımasına imkân tanıdığı için tercih edilmiştir (Yıldırım ve Şimşek, 2008, 223). İçerik analizinde inceleme aşaması iki araştırmacı tarafından gerçekleştirilmiştir. İlk aşamada yazılı hale getirilen görüşme verilerinin incelenmesine başlanmıştır. İnceleme sürecinde daha önce araştırma sorularıla belirlediğimiz kaşıklar, ütüler, aydınlatma araçları, tarım araçları temaları etrafında verilerde sık tekrarlanan ve öne çıkan ifadeler belirlenerek kodlar oluşturulmuştur. Her iki araştırmacı tarafından belirlenen kodlar karşılaştırılarak kesinleştirilmiştir. $\mathrm{Bu}$ şekilde araştırmanın tutarlı̆̆ı sağlanmaya çalışılmıştır. Sonra da araştırma sürecinde belirlediğimiz temalar ve elde edilen yeni kodlar çerçevesinde görüşme verileri iki araştırmacı tarafından birbirilerinden bağımsız olarak analiz edilmiştir. İki araştırmacı tarafından ayrı ayrı yapılan veri analiz sonuçlarının karşılaştırılması "görüş birliği" ve "görüş ayrılığı" olan konular tartışılmış ve gerekli düzenlemeler yapılmıştır. Araştırmanın güvenilirlik hesaplaması için Miles ve Huberman'ın (1994) önerdiği güvenirlik formülü (Güvenirlik = Görüş Birliği/ (Görüş Birliği + Görüş Ayrılığı) kullanılmıştır. Güvenirlik yüzdesi \% 80'dir. Güvenirlik hesaplarının \%70'in üzerinde çıkması, araştırma için güvenilir kabul edilmektedir (Miles ve Huberman, 1994). Ayrica çocukların söylemlerinin örneklendirilmesi açısından doğrudan alıntılara yer verilerek dış güvenirliği arttırılmaya çalışılmıştır. Alıntılarda etik açıdan doğru olmayacağı düşünülerek çocukların isimlerine yer verilmemiş, onun yerine çocuklar Ö1, Ö2 gibi kod isimleriyle tanımlanmıştır.

\section{BULGULAR}

$\mathrm{Bu}$ araştırma bir takım etkinlikler yoluyla erken çocuklukta çocukların kronolojik düşünme becerisini etkileyen faktörleri belirlemeyi ve kronolojik düşünme becerilerinin nasıl geliştirilebileceğinin cevabını bulmayı amaçlamıştır. Araştırmada elde edilen veriler betimsel ve içerik analizi tekniğine uygun olarak alt problemler kapsamında çözümlenmiş ve aşağıdaki bulgular elde edilmiştir.

\subsection{Birinci Alt Problem Görsel Zaman Çizelgesine Yönelik Bulgular}

Çocukların kronolojik olarak sıraladıkları görsel zaman çizelgesi sonuçları Tablo 3'te gösterilmiştir.

Tablo 3. Kaşıklar, Ütüler, Aydınlatma ve Tarım Araçlarının Kronolojik Sıralamasına Yönelik Sonuçlar

\begin{tabular}{lccc}
\hline & $52-60$ Aylık & 61-72 Aylık & $\mathrm{f}(\mathrm{n}=12)$ \\
\hline Kaşıklar & 5 & 7 & 12 \\
Ütüler & 2 & 4 & 6 \\
Aydınlatma Araçları & 3 & 4 & 7 \\
Tarım Araçları & 1 & 6 & 7 \\
\hline
\end{tabular}

Tablo 3'e bakıldığında, küçük ve büyük yaş grubu çocukların tamamının eski ve yeni kaşığı kronolojik olarak sıralayabildiği ve böylece en başarılı kronolojik sıralamayı yapabildikleri görülmektedir. Tablonun tümü değerlendirildiğinde büyük yaş grubunun genel olarak kronolojik sıralamada küçük yaş grubundan daha başarılı olduğu anlaşılmaktadır. Sonuç olarak okul öncesi dönemde 4,5 yaşından itibaren çocukların kronolojik sıralamada \% 56 ile ortalama bir başarı ve 5 yaşından sonra ise \% 60 oranında küçük yaş grubundan az bir farkla ortalamanın üzerinde başarı gösterdikleri ileri sürülebilir. Çocukların eski ve yeni olanı nasıl ayırt edip kronolojik olarak sıraladığı yüz yüze yapılan görüşme ile çözümlenmeye çalışılmıştır. 
3.2 İkinci Alt Problem Kaşıkların Kronolojik Sıralamasını Belirleyen Faktörlere Yönelik Bulgular

3.2.1 Çocukların eski ve yeni kaşı̆̆ı belirlemesinde etkili olan faktörler nelerdir?
Veriler incelendiğinde çocukların yakın geçmişe ve şimdiye ait kaşığı nasıl tespit ettiğine yönelik görüşleri Tablo 4'teki temalar (Tahta kaşık, metal kaşık) ve kodlar (Siyah, tahta, metal vb.) altında şu şekilde toplanmıştır:

Tablo 4. Kaşıkların Kronolojik Sıralamasını Doğru Yapan Çocukların Görüşleri

\begin{tabular}{|c|c|c|c|}
\hline Yaş Grubu & Tahta Kaşık & $f(n=12)$ & Metal Kaşık \\
\hline \multirow[t]{5}{*}{ 52-60 aylik } & Siyahlığından & 2 & Beyazlığından \\
\hline & & & Metalden \\
\hline & Tahtadan & 2 & $\begin{array}{l}\text { Yaşlı olmayan insanlar } \\
\text { [kullanır] }\end{array}$ \\
\hline & Çok sert & 1 & Camdan \\
\hline & & & Bilmiyorum \\
\hline \multirow[t]{3}{*}{ 61-72 aylik } & Metal & 1 & Metalden \\
\hline & Koyu & 1 & Demirden \\
\hline & Tahtadan & 5 & \\
\hline \multicolumn{3}{|c|}{$\begin{array}{l}\text { Tablo } 4 \text { incelendiğinde küçük yaş grubu çocuklar } \\
\text { genel olarak kaşığın eski olma nedenini } \\
\text { "siyahlığı” ve "tahta" olma özelliği ile açıklarken }\end{array}$} & \multirow{8}{*}{$\begin{array}{l}\text { sonuçlar da göz önüne alındığında küçük yaş } \\
\text { grubu çocuklarının başarılı bir kronolojik } \\
\text { sıralama yapmasında görsel algılamanın ve } \\
\text { günlük yaşam deneyimlerinin; daha büyük yaş } \\
\text { grubu çocuklarında ise görsel algılama ile } \\
\text { birlikte kendilerine aktarılan malzemenin türü } \\
\text { ile ilgili bilgiyi kullanmalarının etkili olduğu ileri } \\
\text { sürülebilir. Genel olarak tüm çocukların } \\
\text { kaşıkları, diğer araç-gereçlere göre kronolojik } \\
\text { olarak daha başarılı sıralamasında, kaşığın } \\
\text { çocukların günlük yaşam deneyimleriyle birebir } \\
\text { ilişkili bir araç-gereç olması da etkili olmuş } \\
\text { olabilir. Bu ilişkinin, çocuklarda geçmiş ile } \\
\text { bugüne dair başarılı bir kronolojik algı } \\
\text { oluşturmasına sebep olduğuileri sürülebilir. }\end{array}$} \\
\hline \multirow{4}{*}{\multicolumn{3}{|c|}{$\begin{array}{l}\text { büyük yaş grubu çocuklar renkten daha ziyade } \\
\text { "tahta” olma özelliği ile ilişkili olarak } \\
\text { açıklamaktadır. Tahta kaşığın eski olma } \\
\text { nedeniyle ilgili küçük yaş grubunun görüşlerine } \\
\text { bakıldığında “....çünkü bu siyah tahta o yüzden. }\end{array}$}} & \\
\hline & & & \\
\hline & & & \\
\hline & & & \\
\hline \multicolumn{3}{|c|}{$\begin{array}{l}\text { Eski kaşıklar yaşlılarda kullanılan bir eşya” (Ö2), } \\
\text { “....çünkü tahtadan yapılmış” (Ö5,) şeklinde } \\
\text { ifadelere rastlanmaktadır. Kaşığın yeni olma }\end{array}$} & \\
\hline \multicolumn{3}{|c|}{ gerekçesine yönelik görüşler incelendiğinde } & \\
\hline \multicolumn{3}{|c|}{$\begin{array}{l}\text { küçük yaş grubu çocukların günlük yaşam } \\
\text { deneyimlerine paralel olarak “....yaşlı olmayan } \\
\text { insanlar kullanır” (Ö2), “....metalden yapılmış” }\end{array}$} & \\
\hline
\end{tabular}
(Ö3), "metalden", "beyazlığından", "camdan" şeklindeki somut kanıtları kullandıkları görülmektedir. Büyük yaş grubu çocuklar kaşığın yeni olma nedenini, “....metalden yapılmış” (Ö8), “....çünkü parlak ve metalden” (Ö10) şeklinde ifade ederek malzemenin metal olma özelliği ile ilişkili olarak açıklamaktadır.

Küçük çocukların başarılı bir kronolojik sıralama yapmasinda ve bunu renge dayalı olarak açıklamasında geçmiş döneme ait olarak kendilerine gösterilen bazı kap kaçakların renklerinin siyaha yakın olmasının etkili olduğu düşünülmektedir. $\mathrm{Bu}$ durumla birlikte diğer

3.3 Üçüncü Alt Problem Ütülerin Kronolojik Sıralamasını Belirleyen Faktörlere Yönelik Bulgular

3.3.1 Çocukların uzak geçmişe, yakın geçmişe ve şimdiye ait ütüyü belirlemesinde etkili olan faktörler nelerdir?

Veriler incelendiğinde çocukların uzak geçmişe, yakın geçmişe ve şimdiye ait ütüyü nasıl tespit ettiğine yönelik görüşleri Tablo 5'teki temalar (Taş ütü, mangal ütü, elektrikli ütü) ve kodlar (Çok çok siyah, çok siyah koyu, taş vb.) altında şu şekilde toplanmıştır:

Tablo 5. Ütülerin Kronolojik Sıralamasına Doğru Yapan Çocukların Görüşleri

\begin{tabular}{|c|c|c|c|c|c|c|}
\hline Yaş & & & & & & \\
\hline Grubu & Taş Ütü & $f(n: 6)$ & Mangal Ütü & $f(n: 6)$ & Elektrikli Ütü & $f(n: 6)$ \\
\hline
\end{tabular}




\begin{tabular}{lllllll}
\hline 52-60 & Çok çok siyah & 1 & Yaşlı eşyaları & 1 & Şimdi gördüm & 1 \\
aylık & Çok siyah & 1 & Konakta & 1 & Evde & 1 \\
\hline & Koyu & 1 & Konakta & 2 & Evde & 2 \\
$61-72$ & Taş & 2 & Koyu & 1 & Terzide & 1 \\
aylık & Çok eski & 1 & Yaşlılar... & 1 & Metal & 1
\end{tabular}

Tablo 5'te görüldüğü gibi ütülerin 3'lü kronolojik sıralamasını küçük yaş grubunda 2, büyük yaş grubunda 4 çocuk doğru sıralayabilmiştir. Üçlü kronolojik sıralamada, en eski ütü olan taş ütüyü küçük yaş grubu çocukların "....işte çok siyah" (Ö2), “....çok çok siyah olduğu için” (Ö4) gibi ifadelerle renge dayalı açıklamalar yaparak belirlemiş oldukları görülmektedir. Büyük yaş grubundaki çocuklardan taş ütünün en eski ütü olma nedeni "Koyu olduğu için" (Ö7), “....çünkü bu taş” (Ö9), “....çünkü taş devrinden kalma" (Ö11) sözleri, çocukların eşya ve araçgereçleri kronolojik sıralarken önceliğini belirlemede genel olarak "renk" ve "materyal" özelliklerini temel aldıklarını göstermektedir. Çocuklardan dördü mangal ütüyü kronolojik sıralamada "konakta gördüm" sözleriyle açıklama getirip ikinci sıraya koymuştur. Mangal ütüyü sinifta sunumda ve daha önce gezdikleri konakta görmelerinden dolayı yer ve zaman ilişkisi kurup yeni ütüye göre daha yakın zamana dayandırıp kronolojik olarak ikinci sıralamaya koydukları düşünülebilir. Çocukların “....çünkü o yaşlılardan gelmiş ...” (Ö11) ve “....yaşlı olanların eşyaları böyle olur" (Ö2) gibi sözleri ise başarılı bir kronolojik sıralamada çocukların yaşlı insanlarla etkileşimi yer gibi farklı bir etki oluşturmuş. Ayrıca yaşlıların da zamansal açıdan kendilerinden farklı olduğunu ifade etmişler ve bu da çocukların eşya ve insanın zaman ilişkisini kavrayabildikleri şeklinde yorumlanabilir. Yeni elektrikli ütüyü, “...evde gördüm” (Ö6), “....terzide gördüm” (Ö7) ifadeleri günlük yaşamlarında gördükleri ütü ile ilişkilendirerek "yeni ütü" olduğuna karar verdiklerini göstermektedir. Diğer çocukların, "Bu da metal" (Ö9) ifadesi ütünün nitel (hammadde) özelliğinin doğru bir kronolojik sıralamada etkili olduğunu düşündürtmektedir.

Sonuç olarak ütülerle ilgili üçlü bir kronolojik sıralamayı başarı ile yapan çocukların en eskiyi belirlemede siyah rengi ve taş olmasını referans aldıkları görülmektedir. Siyah rengin özellikle küçük yaş grubu için tarihsel düşünme becerileri açısından "geçmişi" ve özellikle kronolojik sıralamada en eskiyi belirlemede ayırt edici önemli bir kavramsal şema olduğu düşünülebilir. Çocukların kronolojik sıralamada genel olarak daha yakın zamana ait ütüyü belirlemede ise geçmiş zamana ait gördükleri mekân (konak) ve yaşlı insanların eşyalarının etkili olduğu görülmektedir. En yakın zamana ait ütüyü belirleyip, kronolojik sıralamada ise kendi günlük yaşam alanı içerisindeki mekânlarda bu gereci görmesiyle ilişkili olduğu düşünülmektedir.

\subsection{Beşinci Alt Problem Tarım Araçlarının Kronolojik Sıralamasını Belirleyen Faktörlere Yönelik Bulgular}

3.5.1 Çocukların uzak geçmişe ve şimdiye ait tarım araçlarını belirlemesinde etkili olan faktörler nelerdir?

Veriler incelendiğinde çocukların uzak geçmişe ve şimdiye ait tarım araçlarının nasıl tespit ettiğine yönelik görüşleri Tablo 6'daki temalar (Karabasan ve traktör) altında toplandığı görülmektedir. Çocukların değindikleri ifadeler birbirinden bağımsız kodlarla şu şekildedir:

Tablo 6. Aydınlatma Araçlarının Kronolojik Sıralamasını Doğru Yapan Çocukların Görüşleri

\begin{tabular}{llclclc}
\hline Yaş Grubu & Mum & $\mathrm{f}(\mathrm{n}: 7)$ & $\begin{array}{l}\text { Gaz } \\
\text { Lambası }\end{array}$ & $\mathrm{f}(\mathrm{n}: 7)$ & Ampul & $\mathrm{f}(\mathrm{n}: 7)$ \\
\hline 52-60 aylık & Anladım ya & 1 & Cevap yok & 2 & Cevap yok & 1
\end{tabular}




\begin{tabular}{lllllll}
\hline & Yangın yandığı için & 1 & İşte & 1 & Yeni lamba & 1 \\
& Cevap yok & 1 & & Ev de & 1 \\
\hline $\begin{array}{l}\text { 61-72 } \\
\text { Aylık }\end{array}$ & Mum olacak & 1 & Konakta & 1 & $\begin{array}{l}\text { Babamın iş } \\
\text { yerinde }\end{array}$ & 1 \\
& $\begin{array}{l}\text { Hep mumyalar } \\
\text { vardı eskiden }\end{array}$ & 1 & Eski bir şeye & 1 & Cam & 2 \\
& Anladım & 1 & Koyu & 1 & Sinıfımızda & 1 \\
& Daha eskiler & 1 & Gaz lambası & 1 & & \\
\end{tabular}

Tablo 6' da görüldüğü gibi küçük yaş grubundan 3 çocuk aydınlatma araçlarını kronolojik olarak sıralayabilmiştir. Görüşme sonuçları analiz edildiğinde çocukların mumun en eski aydınlatma aracı olma sebebini ve ikinci sırada neden gaz lambasını sıraladıklarını mantıklı bir şekilde açıklayamadıkları görülmüştür. $\mathrm{Bu}$ sıralamayı kısmen sezgisel ve/veya izledikleri ve gördüklerinden yola çıkarak yaptıkları düşünülmektedir. Buna karşın ampulü bir çocuğun “....çünkü yeni lambalar böyle [tavanı göstererek] bizimki süslü" (Ö1) açıklaması ile diğer bir çocuğun “....evde” (Ö5) gördüklerini içeren açıklamaları, çocukların yeniyi belirlemede günlük yaşamları ile ilişkili kanıtlar göstererek cevaplayabildiklerini göstermektedir. Büyük yaş grubunda 4 çocuk aydınlatma araçlarını kronolojik olarak dizebilmiştir. Bu yaş grubu çocuklardan Ö11'in mumun en eski olma sebebini, "....çünkü hep mumyalar vardı eskiden" açıklayarak, mumyaları geçmişle bağdaştırıp kanıt göstererek doğru sıralamayı yaptığı düşünülebilir. Diğer üç çocuk ise tam bir gerekçe gösterememiştir. Onların sezgilere ve/veya çağrışımlara dayalı olarak mumun en eski aydınlatma aracı olduğunu tespit ettiği düşünülmektedir. Çocukların gaz lambasının ampulden daha eski olarak sıralama nedenleri farklılık göstermektedir. Ö7 “....çünkü koyu” gerekçesini ileri sürerek renk sınıflandırmasını işe koşmuş; Ö9 ise “çünkü ampul daha yeni.
Çünkü şimdi sınıfımızda da ampul kullanılıyor" açıklaması ile ampulü kanıt göstererek gaz lambasının daha eski, ampulün ona göre daha yeni olma gerekçesini ileri sürmüştür. Çocukların ampulün şu anda kullanılan yeni bir aydınlatma aracı olduğunu "Çünkü şimdi sınıfımızda da ampul kullanılıyor" (Ö9) ve “Babamın iş yerinde gördüm” (Ö6) ifadeleri ile yakın çevrelerini ve “...çünkü camdan yapılmış"(Ö11) ifadesi ile hammaddenin kanıt göstererek ifade ettiği görülmektedir. Büyük yaş grubu çocukların mumun eski olduğuna dair bir algilarının olduğunu görülmekle birlikte, bugün ve daha yakın bir geçmişe ait deneyim ve gözlemlerinden yararlanarak mantıksal bir çıkarımla başarılı bir kronolojik sıralama yaptıkları ileri sürülebilir.

\subsection{Beşinci Alt Problem Tarım Araçlarının Kronolojik Sıralamasını Belirleyen Faktörlere Yönelik Bulgular}

3.5.1 Çocukların uzak geçmişe ve şimdiye ait tarım araçlarını belirlemesinde etkili olan faktörler nelerdir?

Veriler incelendiğinde çocukların uzak geçmişe ve şimdiye ait tarım araçlarının nasıl tespit ettiğine yönelik görüşleri Tablo 7'deki temalar (Karabasan ve traktör) altında toplandığı görülmektedir. Çocukların değindikleri ifadelerin kodları genel olarak birbirinden bağımsız olarak şu şekildedir:

Tablo 7. Tarım Araçlarının Kronolojik Sıralamasını Doğru Yapan Çocukların Görüşleri

\begin{tabular}{llclc}
\hline Yaş Grubu & Karasaban & $\mathrm{f}(\mathrm{n}: 7)$ & Traktör & $\mathrm{f}(\mathrm{n}: 7)$ \\
\hline 52-60 aylık & Çayırları güçlendirmek için & 1 & Traktör hep yeni & 1 \\
\hline 61-72 aylık & Eskiden traktör yoktu & 1 & Traktör. & 1 \\
& Cevap yok & 1 & Araba. & 1 \\
& Araba değil & 1 & Cevap yok & 3 \\
\hline
\end{tabular}




$\begin{array}{ll}\text { Çok eski } & 1 \\ \text { Eskiden kendi ekmeklerini kendileri } & 1 \\ \text { yapıyordu } & \\ \text { Öküz işte } & 1\end{array}$

Tablo 7'de görüldüğü gibi küçük yaş grubunda sadece bir kişi (Ö1) tarım araçlarını kronolojik olarak doğru sıralayabilmiştir. Karasabanın traktörden daha eski olmasını "....çünkü çayırları güçlendirmek için böyle yürütürlermiş" (Ö1) açıklamasını getirmiştir. Traktörün yeni olma sebebini “....traktör hep yeni çıar. Çünkü bazıları yeniymiş" (Ö1) gibi ifadelerle açıklamıştır. Bu ifadeler bize sinıfta gösterilen karasaban ve traktör ile ilgili temsili resimlerin, fotoğrafların ve tarımın nasıl yapıldığının ve traktörün yeni bir araç olduğunu bilgisinin Ö1 tarafından anlaşıldığını göstermektedir. $\mathrm{Bu}$ durumda Ö1'de tarihsel düşünme becerileri açısından değişim kavramına dair bir şemanın oluştuğu düşünülebilir. Diğer çocukların yanlış bir kronolojik siralamada yanilgiya düşmelerinde en belirgin neden olarak geçmişi tanımlayıcı bir şema olarak referans aldıkları "siyah renk" sınıflaması olduğu ileri sürülebilir.

Tablo 7'de görüldügü gibi büyük yaş grubu 6 çocuk tarım araçlarını kronolojik olarak doğru sıralayabilmiştir. $\mathrm{Bu}$ yaş grubu ile yapılan görüşmede kronolojik düşünme becerisinin gelişimine dair kabul edilebilir cevaplar gelmiştir: Karasabanın eski olma sebebini Ö6 “....çünkü eskiden traktör yoktu. Eskiden böyle şeyler inek..." sözleriyle açıklamıştır. Ö6'nın somut olarak traktörün kronolojik sıralamada yaşadığı döneme ait bir araç olduğunu açılayamasa da bildiği görülür. Açıklamalarından geçmişte tarlada ineklerle birlikte karasabanın kullanıldığını da öğrendiği söylenebilir. Bu durum Ö6'nın bir "geçmiş" algısına ve değişime dair bir farkındalığa sahip olduğunu ve dolayısıyla tarihsel düşünebilme becerisinin temel öğelerinin oluştuğunu göstermektedir. Karasabanın eski olma gerekçesini Ö9 ise "Çünkü buradaki araba değil. Buradaki araba [Traktörün olduğu resmi göstererek]. Traktör de bir araba. 70'mişlerde araba olmadığı için böyle bağlıyorlardı [Öküzü göstererek]”. Ö12 “....çünkü tarla var. Eskiden kendi ekmeklerini kendileri yapıyordu" ifadeleri ile geçmiş kavramını kullanarak değişim kavramina dair kapalı bir vurgu yaparak neden sonuç ilişkisi içerisinde insanların geçmiş yaşam tarzı ile bağlantı kurarak kronolojik sıralamayı doğru yapabildiği düşünülebilir.

Görüşme sonuçları analiz edildiğinde tarım araçları hakkında şimdi ve geçmişe dair çok az ya da hiçbir deneyime sahip olmayan küçük yaş grubu çocuklarının başarılı bir kronolojik sıralama yapamadıkları görülmektedir. Büyük yaş grubu çocuklarının neredeyse tamamına yakını ikili kronolojik sıralamada tarım araçlarını doğru sıralayabilmiştir. Görüşme sonuçlarına bakıldığında çocukların geçmişteki yaşamı fark ettikleri ve neden sonuç ilişkisi içerisinde bugünden farklı yaşam koşullarının olduğunu algılayıp değişimi fark ettikleri ileri sürülebilir.

\section{SONUÇ, TARTIŞMA VE ÖNERİLER}

Araştırma sonuçları, 4,5-5 yaş arasındaki çocukların geçmiş zamana ait değişimi kronolojik olarak sıralamada ortalama bir başarı (\%56), 5 yaşından sonra ise ortalamanın üzerinde bir başarı ( $\%$ 60) gösterdiklerini ortaya koymuştur. Benzer şekilde Bernt ve Wood (1974: 826) araştırmalarında Piaget'in (1969) aksine işlem öncesi dönemde (2-7 yaş) çocukların süreç hakkında karar verecek ilkel bir kapasitelerinin olduğunu görmüşlerdir. Friedman'da 5 yaşından sonra çocukların bir günden daha uzun bir yapıyı genellikle öğrendiklerini ortaya koymuştur (Friedman, 1977: 1991).

Araştırma sonuçları, çocukların en başarılı ikili kronolojik sıralamayı kaşık sıralamasında yaptıklarını göstermiştir. Bu sonuç kaşığın, çocukların günlük yaşantılarında en çok deneyime sahip oldukları somut araç olması ile açıklanabilir. Bu da bize çocukların kronolojik düşünebilme algısının, zamanı günlük yaşam deneyimleriyle somut olarak 
ilişkilendirebilmesine bağlı olarak arttı̆̆ını düşündürtmektedir. Öyle ki Jahoda da (Steele, 1976), 5 yaş civarında çocukların "zaman ve uzay hakkında" kafalarının karıştığını fakat zamanı "özel nesne, yer ve olaylarla" ilişkilendirdiklerinde bu karmaşayı azalttıklarını gözlemlemiştir (Akt. Dilek, 2001: 81). Zembat ve diğerleri (2014) yaptıkları araştırmada 48-54 aylık çocukların kendileri ile ilgili bir anlatıda soyut geçmişi somutlaştırdıkları ve günlük yaşamlarında geçmişle ilgili kavramları başarı ile kullandıklarını ve çeşitli kültürel öğelerle karşılaştırılması durumunda onların geçmişe yönelik algılamalarının geliştirilebilir olduğunu ortaya koymuşlardır. Bu çalışmayla, Friedman'ın (1977: 1599) özellikle kendini sözel olarak ifade etmede zorlanan küçük çocukların kullandıkları zaman kavramını daha fazla değerlendirebilmek için "somut materyaller kullanilabilir" önermesinin de, doğrulandığı ileri sürülebilir.

Araştırma sonuçlarına göre küçük yaş grubu (5260 ay) çocuklar, materyalin eskiliğini hammaddesi ile birlikte renginin koyuluğu ve siyahlığ ile ilişkilendirerek belirlemiştir. Sınıf içi etkinlikte eski zamanlarda konaktaki yaşamla ilgili gösterilen resimlerde bazı kap kacakların renginin siyah olması çocuklarda bu algıyı oluşturmuş olabilir. Siyah rengin genel olarak tarihsel düşünme becerileri açısından geçmişliği ve özellikle kronolojik siralamada en eskiyi belirlemede ayırt edici önemli bir kavramsal şema olduğu ileri sürülebilir. Bu şemanın genellikle küçük çocuklar tarafından geçmişe dair yeterli bilgilerinin ve deneyimlerinin oluşmadığı bir konuda kronolojik sıralama yaparken önemli bir referans olarak başarılı bir şekilde işe koşulduğu iddia edilebilir.

Büyük yaş grubu (62-74 ay) çocukların ise nesnenin eski ve yeni oluşunu belirlemede, renkten daha ziyade nesnenin malzemesinin tahta ve metal olma niteliğine göre onu ayırt edip kronolojik olarak sıraladığı görülmüştür. Çocukların açılamalarından görsellikle birlikte zihinsel gelişimine koşut olarak nedensellikle ilişkisi içerisinde geçmiş ile bugüne dair bir algı oluşturduğu ileri sürülebilir. Ayrıca tarım araçlarını kronolojik sıralarken büyük yaş grubu çocuklarının insanların geçmiş yaşam tarzı ile bağlantı kurarak değişim kavramına dair kapalı bir vurgu yaparak neden sonuç ilişkisi içerisinde kronolojik sıralamayı doğru yapabildiği görülmüştür. Bu bulgular, 62-74 aylık çocukların, kronolojik düşünmelerinde değişim ve/veya sebep gibi anahtar kavramları işe koşarak sağlıklı bir zaman duygusu geliştirdiğini göstermektedir. Bu sonuç, Hoerl ve McCormack'in (t.y.:4) okul öncesi çocuklarının zamansal düzeni nedensel kararlar ile başarılı bir şekilde sıraladığı sonucunu desteklemektedir. Levin ve Gilat (1983: 83) zamanla ilgili bir sıralamada doğru cevaplar veren çocukların büyük çoğunluğunun mantıklı açılamalar yaptığı, boyuttan daha ziyade zamanla ilgili parlak çıkarımlarda bulunduğunu tespit etmiştir.

İkili ve üçlü bir kronolojik sıralamayı başarı ile yapan küçük yaş grubu (52-60 aylık) çocukların zaman olarak uzak geçmişe ve yakın geçmişe ait materyali belirlemede mantıksal bir açılamadan ziyade sezgilere ve/veya çağrışımlara ve deneyimlere dayalı algılarından bahsedilebilir. Seefeldt, Castle ve Falconer (2015) küçük çocuklarda sezgisel ve geleneksel bir zaman algısı olduğundan bahseder. Bu algının hatalara neden olduğuna da dikkat çeker. Onlar, sezgisel düşünce ile oluşan sezgisel zaman algısını kronolojik zaman algısından ayırır. Sezgisel düşünce, Piaget ve takipçilerinin tarihsel düşünme becerisinin gelişiminin bilişsel düzeyde açılanamadığı durumlarda bahsettikleri bir düşüncedir. Bu düşünceye göre küçük çocuk çevresini hayvanlara benzer şekilde "zeka gelişiminin dayanağı olmayan" "iç-dürtüleri" aracılığıyla algılar. Çevresindekileri kendi etkinliği sırasında fiziksel deneyimleriyle kazanır. Dolayısıyla somut deneyimleri dışındaki kavramları ve nesneleri anlamaları zordur. Bu anlayışa karşı olan Watts, sezgisel düşünmenin kaba ve bilişsel gelişimde terk edilmesi gereken bir düşünce olmadığını ifade ederken bunu çağrışımsal düşünme olarak niteleyerek gerçekçi düşünmede de önemli bir rol oynadığına dikkat çeker (Dilek, 2007: 50-61). Binet "bilinçsiz etkileri beynimize gönderen 
değişikliklerin sürekliliği tespitinden hareketle, çıkış noktasını tahmin edemediğimiz bu değişik etkilerin, bilincin ışığında, aniden ortaya çıkan fikir ve önerme gücüne sahip oldukların ifade eder" (Akt. Dilek, 2007: 62). Harlan (1992), Healy (1997), Mishove (1995), Gagatsis ve Patronis (1990), Kolb (1984), Gardner (1983) rasyonel bilginin sol yarımkürede oluştuğunu sezgisel bilginin ise "sözel olmayan, ani algılamalar" olup "sağ yarımkürede" oluştuğunu belirtir. Sağ beyin sezgisel düşünmeyi organize etmekle birlikte aynı zamanda "tümdengelim tarzda düşünmeyi, sentezci düşünmeyi de" düzenler (Akt. Güven: 1). Örneğin Wheatley (1977) “Einstein'ın aritmetikte sol beyin işlemlerini gerektiren işlerde çok iyi olmadığını ifade etmiştir". Büyük keşiflerini semboller, kelimeler üzerine kurmaktan daha ziyade beyninde aniden ortaya çıkan şekiller üzerine kurduğunu belirtmiştir. Einstein'ın "sağ beynini daha etkin" kullanarak bu şekilde "daha bütünleştirici, sezgisel, analojik ve somut düşündüğünü" ileri sürebiliriz (Akt. Güven, tb: 2). Nitekim Vygotsky'e (1985) göre sezgisel /çağrışımsal düşünme yoluyla "çocuğun insana şaşkınlık veren bağlantılar kurup genellemeler de bulunabildiği, insanı hayrete düşüren geçişler yapabildiği herkesçe bilinmektedir" (Akt. Dilek, 2007: 62). Dolayısıyla çocukların sahip olduğu çağrışımsal düşünme tarihsel düşünme becerilerinin geliştirilmesinde önemli bir basamaktır. Nitekim Vukelich ve Thornton (1990) 4-5 yaşlarındaki çocukların olayları sıralamak adına belli bir algı geliştirebildiğinden bahseder. Freedman (1991: 140) geçmiş, şimdi ve gelecek zaman ve basit zaman (dün, bugün, yarın) hakkında bilgi sahibi olmadan da küçük çocukların geçmişteki olayların zamanını bilebildiklerini ileri sürmüştür. McReiney ve Russick'e (2010: 24) göre, küçük çocukların zaman çizelgesinde yaptıkları sıralamalar her zaman başarılı bir şekilde olmamasına karşın, en sevdikleri hikâyelerde prenses ve dinozorları gösterirlerken içinde bulunulan zamandan geriye doğru rahatlıkla hareket edebilmektedirler. Tarihin içerisinde çoğunlukla en önce, en son, en iyi ve en kötüyü değerlendirebilir. Farris (2001) beş yaşına kadar çocukların basit zaman (dün, bugün, yarın) birimlerini anlayabildiklerini; cümle içinde zaman kavramını kullanabildiklerini ve bir gün içindeki olayları sıralayabildiklerine dikkat çeker. Üstünel (2007) çocukların zaman kavramını yeni öğrendiklerinde bugün ve yarın kavramlarını yer yer karıştırdıklarına "sonra", "belirli bir zaman sonra" gibi kelimelerin ise çocuklara bir şey ifade etmediğini açıklamaktadır (Kok, 2012: 41). Nitekim Dilek'in (2007: 83) de belirttiği gibi “çocukların zamanı kronolojik olarak anlamakta bazı güçlüklerle karşı karşıya oldukları" kabul edilmelidir.

Çocukların kronolojik düşünmede daha yakın zamana ait materyalleri belirlemede ise geçmiş zamana ait gezip gördükleri mekânı ve yaşlı insanların eşyalarını referans aldıkları belirlenmiştir. Bu durum çocukların, eşya ve insanın zaman ilişkisini kavrayabildikleri düşündürmüştür. Onlar, yakın zamana ait nesneleri kronolojik siralamada belirlerken kendi günlük yaşamında deneyimlemesi ve en yakın çevresinde görmesiyle ilişkilendirerek böyle bir sonuca ulaşmışlardır. Briod'un (1986: 12) ifade ettiği gibi geçmişlik duygusu çeşitli farklı deneyimlerin yansımasıdır. Vukelich ve Thorndon (1990: 22) erken yaşlarda küçük çocukların zaman kavramını anlamaya başlamasını, günlük deneyimlerinde geçmişi ve bugünü doğru bir bağlam içerisinde kullanmalarına bağlar. Çünkü tarihsel öğrenme geçmişi ve şimdiyi ayırt etme becerisini gerektirir. Çocuklar günlük işlerle uğraşmaya başlayınca zaman olgusunu anlar (Wortham, 2005, Akt. Çoşkun-Keskin, 2016).

Poster, tarihsel bir zaman algısının oluşumu için geçmiş, şimdi ve gelecek kavramlarının gerekli olduğunu ancak yeterli olmadığını vurgulamıştır (Alleman ve Brophy, 2003). Egan (1982), bu zorluğu aşmak için erken yaşlarda çocuklara verilecek bir tarih öğretiminin ilk aşamasında, kronolojik düşünme becerisinin gelişimini hedefleyen etkinliklerde ve öykülerde, kurgunun kronolojik olarak çözümlenmesini ve çocukların yaşadığı döneme ait önemli gün ve olayları 
takvim üzerine yerleştirmesini tavsiye etmektedir. Fivus (1994) buna yönelik olarak ebeveynlerin, yetişkinlerin ve öğretmenlerin çocuğun geçmişte yaşadığı bir anıyı anlatırken eksik anlattıkları kısımları tamamlamalarını, tanık oldukları durumlarla ilgili çocuğun yanlış hatırladıklarını düzeltmelerini, daha tutarlı ve daha özenli olarak hatırladıklarını yeniden anlatmalarını yavaş yavaş sağlamaya çalışmasını önermektedir (Akt. Zembat vd., 2014: 210).

Araştırmadan elde edilen sonuçlar doğrultusunda, okul öncesi eğitim kurumlarında çocukların planlı bir biçimde ve ilgileri doğrultusunda yapılacak etkinlikler yoluyla zaman algisının sadece basit zaman (dün, bugün, yarın) olarak değil fiziksel zaman (geçmiş, şimdi, gelecek) olarak da geliştirilebileceği, sebep, sonuç, değişim ve süreklilik kavramları doğrultusunda çocukların günlük yaşam deneyimleriyle iç içe etkinliklerle onlara kronolojik düşünme becerisini kazandırmanın mümkün olabileceği ve kendi düzeylerine uygun öğrenme ortamlarının oluşturulabileceği düşünülmektedir. Nitekim Drake ve Nelson da (2005: 83) tarihsel süreçte değişim ve süreklilik arz eden özne, nesne veya olayda tarihsel yapıların gösterilmesini önemli bulur. Böylece çocukların kronolojik düşünme becerilerinin geliştirilerek belirli bir zaman periyodunda ilişkileri sebep sonuç ilişkisi içerisinde anlamalarına yardımcı olunacağını belirtir.

Genel bağlamda çocuklara zaman kavramı kazandırılırken dün, bugün ve yarın kavramlarını içeren basit zamana yönelik etkinlikler ile birlikte sebep, sonuç, değişim ve süreklilik kavramları doğrultusunda çocukların günlük yaşam deneyimleriyle iç içe geçmiş, şimdi ve geleceği karşılaştıran etkinlikleri düzenlenmelidir. Çocuklara etkinliklerde kendisi ve aile büyüklerinin yaşantısından örnekler sunma fırsatı sağlanmalı; geçmişten günümüze süreklilik arz eden ve değişimi içeren görsel zaman çizelgeleri oluşturmalarına yardımcı olunmalı, tarihi araç-gereçler ya da onların aslına uygun kopyalarıyla çocuklar tanıştırılmalı ve bunların yer aldığı geniş süreçli uygulamalı çalışmalar yaptırılmalıdır. Sanat etkinliklerinde geçmiş ve bugün temalı kesme, renk çalışmaları ile boyama, yapıştırma; kil çalışmaları ve diğer materyallerle geçmişe ve bugüne ait araç ve gereçlerin yapımı; müze ve alan gezileri; geçmiş yaşamı anlatan anı, drama, hikâye ve masal okuma etkinlikleri yapilabilir. Zaman kavramının öğretiminde bilgisayar destekli eğitim okul öncesi eğitimde kullanılabilir. Nitekim Kol (2012), bilgisayar destekli eğitimin “okul öncesi çocuklarında zaman ve mekân kavramlarına yönelik başarı düzeylerine oldukça yüksek düzeyde katkı" sağladığını tespit etmiştir.

Okul öncesi dönemde küçük çocuklarda zaman algisının ve kronolojik düşünme becerisinin gelişmesi için atılması gereken en önemli bir adım da Türkiye'de okul öncesi eğitim programında tarih-sosyal bilgiler öğretimine yer verilmesi, kazanım ve göstergelerin bu başlık altında oluşturulmasıdır. Nitekim küreselleşen dünyada erken çocukluk döneminde tarih öğretimi ile çocukların geçmişe doğru ilk adımlarını atmalarına yardımcı olmak, vatandaşlık ve kimlik kazanımlarını geliştirmeye çalışmak amaçlanmıştır (Aktın ve Dilek: 2014). Sonuç olarak tarih öğretimi erken çocukluk döneminde çocuklarda kimlik duygusunun gelişimine katkı sağlar ve bugünü anlamaları için bir bağlam oluşturmalarına yardımcı olur. Bu kapsamda araştırmacıların okul öncesi dönemde tarih-sosyal bilgiler öğretimine yönelmesinin teşvik edilmesi, araştırmalardan elde edilen sonuçlar doğrultusunda okul öncesi öğretmenlerine tarih-sosyal bilgiler öğretimine yönelik hizmet içi eğitimlerin verilmesi ve başlatılacak uygulamanın yaygınlaştırılması önem arz etmektedir.

\section{Kaynakça}

Aktın, K. ve Dilek, G. (2014). Tarih/Sosyal Bilgiler Öğretim Programlarında Okul Öncesi Dönemde Tarih Öğretimi: ABD Örneği. Uluslarası Avrasya Sosyal Bilimler Dergisi, 5(16), 36-56. 
Alleman, J. and Brophy, J. (2003). History is Alive: Teaching Young Children About Changes Over Time. The Social Studies, 94(3), 107-110.

Berndt, J.T. and Wood. D.J. (1974). The Development of Time Concepts Through Conflict Based on a Primitive Duration Capacity. Society for Research in Child Development, 45(3), 825-828.

Briod, M. (1986). The Young Child's Sense of Time and The Clock. Phenomelogy Pedagogy, 4(1), 8-19.

Çoşkun-Keskin, S. (2016). Erken Çocukluk Döneminde Sosyal Bilgiler Eğitimi ve Sosyo-Kültürel Eğitim. Dursun Dilek (Ed.). Sosyal Bilgiler Eğitimi İçinde (s.353-371). Ankara: Pegem.

Çulha-Özbaş, B. ve Aslan, E. (2008). Çocuklarla Birlikte Tarihsel Düşünme: 12-14 Yaş Grubu Öğrencilerin Tarihsel Kanıta Yönelik Görüşlerini Belirlemek İçin Kaynak Çalışması Geliştirme Etkinliklerinin Değerlendirilmesi. Buca Eğitim Fakültesi Dergisi, 24, 105-112.

Dilek, D. (2007). Tarih Derslerinde Öğrenme ve Düşünce Gelişimi (3. Baskı). Ankara: Nobel.

Drake, F.D. and Nelson, L.R. (2005). Engagement In Teaching History Theory And Practices For Middle And Secondary Teachers. New Jersey: Pearson Merill Prentice Hall.

Egan, K. (1982). Teaching History to Young Children. The Phi Delta Kappan, 63(7), 439-441.

Friedman, W.J. (1991). The Development of Children's Memory for The Time of Past Events. Child Development, 62(1), 139-155.

Friedman, W. J. (1977). The Development of Children's Understanding of Cyclic Aspects of Time. Child Development, 48(4), 1593-1599.

Güven, Y. (TB). Erken Çocukluk Döneminde Sezgisel Düşünme ve Matematik. 2 Ağustos 2016 tarihinde infobank.fedu.odtu.edu.tr/ufbmek-5/b_kitabi/PDF/OkulOncesi/t263d.pdf adresinden erişilmiştir.

Hacısalihoğlu-Karadeniz, M. (2013). Çocukların 'Zamanın Farkında Olma' Becerisini Kavrayabilme Sürecinde Okul Öncesi Eğitim Etkinliklerinin Etkililiğ̈i. Uluslararası Karadeniz Sosyal Bilimler Dergisi, 5(20), 244-266

Hoerl, C. and Mccormack, T. (t.y.). Time in Cognitive Development. Forthcoming in Craig Callender (Ed.): The Oxford Handbook on Time, Oxford University Press . Retrieved From Http://Www.History.Org.Uk/Resources/Primary_Resource_1743_141.Html

Kol, S. (2012). Bilgisayar Destekli Öğretimin (BDÖ) Altı Yaş Çocuklarına Zaman ve Mekân Kavramların Kazandırmaya Etkisi. Yayınlanmamış doktora tezi, Selçuk Üniversitesi Sosyal Bilimler Enstitüsü.

Levin, I., Israeli, E. and Darom, E. (1978), The Development of Time Concepts in Young Children: The Relations Between Duration and Succession. Child Development, 49(3), 755-764.

Levin, I. and Gilat, I. (1983). A Developmental Analysis of Early Time Concepts: The Equivalence and Additivity of The Effect of Interfering Cues on Duration Comparisons of Young Children. Child Development, 54(1), 78-83.

MEB (2013). Okul Öncesi Eğitim Programı Tegm.Meb.Gov.Tr/Dosya/Okuloncesi/Ooproram.Pdf adresinden 2 Nisan 2016 tarihinde erişilmiştir.

Mcrainey, L., Russick, J. (2010). Connecting Kids To History With Museum Exhibitions. Lef Coast Press, United States America.

Miles, M.B. and Huberman, A.M. (1994). Qualitative Data Analysis (2nd edition). Thousand Oaks, CA: Sage Publications.

Seefeldt, C., Castle, S. ve Falconer, R. C. (2015). Okul Öncesi/Ilkokul Çocukları İçin Sosyal Bilgiler Öğretimi. Sevgi Çoskun-Keskin (Çev. Ed.). Ankara: Nobel Yayınevi.

Seggie, F.N. ve Bayburt, Y. (2015). Nitel Araştırma Yöntem Teknik, Analiz Ve Yaklaşımları. Ankara: Anı.

Sönmez, V. ve Alacapınar, F.G. (2014). Örneklendirilmiş Bilimsel Araştırma Yöntemleri. Ankara: Anı.

Vukelich, R., Thorndon, S.J. (1990). Children's Understanding of Historical Time: İmplications for İnstruction. Childhood Education, 67(1), 22-25.

Yıldırım, A., Şimşek, H. (2008). Sosyal Bilimlerde Araştırma Yöntemleri. (7.Bs.). Ankara: Seçkin. 
Zembat, R., Özdemir-Beceren, B., Şengül, T. ve Ünsal, F.Ö. (2013). 6 Year Old Pre-School Children's Perception of "Past". Issues on Education And Research. 3, 299-311.

Zembat, R., Ünsal, F. Ö., Yazıcı, F., Küçükoğlu, E. K., Yıldız, T. Ö. ve Tunçeli, H. İ. (2014). My Own Past: An Example of Family Involvement Project Applied to Improve 48 - 54 Months Old Children's Perception of The Past. International Journal on New Trends in Education and Their Implications, 5(1), 209-215. 